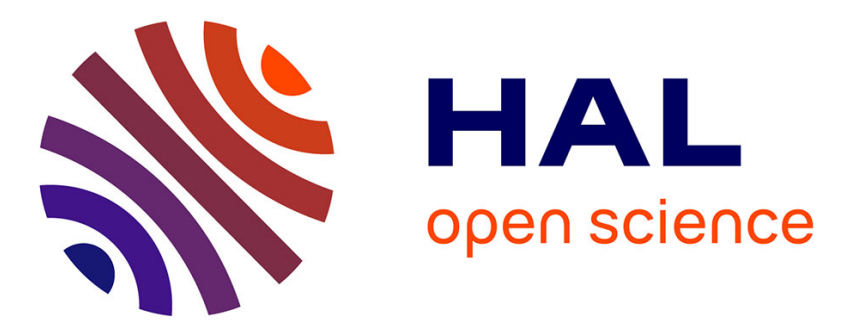

\title{
Screening procedure for evaluating heat load in commercial milks
}

Marie-France Guingamp, Gérard Humbert, Patrick Midon, Marina Nicolas, Guy Linden

\section{- To cite this version:}

Marie-France Guingamp, Gérard Humbert, Patrick Midon, Marina Nicolas, Guy Linden. Screening procedure for evaluating heat load in commercial milks. Le Lait, 1999, 79 (4), pp.457-463. hal00929665

\section{HAL Id: hal-00929665 \\ https://hal.science/hal-00929665}

Submitted on 1 Jan 1999

HAL is a multi-disciplinary open access archive for the deposit and dissemination of scientific research documents, whether they are published or not. The documents may come from teaching and research institutions in France or abroad, or from public or private research centers.
L'archive ouverte pluridisciplinaire HAL, est destinée au dépôt et à la diffusion de documents scientifiques de niveau recherche, publiés ou non, émanant des établissements d'enseignement et de recherche français ou étrangers, des laboratoires publics ou privés. 


\title{
Screening procedure for evaluating heat load in commercial milks
}

\author{
Marie-France Guingamp ${ }^{\mathrm{a}}$, Gérard Humbert ${ }^{\mathrm{a} *}$, Patrick Midon ${ }^{\mathrm{a}}$, \\ Marina Nicolas ${ }^{\mathrm{b}}$, Guy Linden ${ }^{\mathrm{a}}$
}

\begin{abstract}
${ }^{\text {a }}$ Laboratoire des biosciences de l'aliment, unité associée Inra, université Henri-Poincaré, Nancy-I, B.P. 239, 54506 Vandœuvre-lès-Nancy cedex, France

${ }^{\text {b }}$ Centre national d'études vétérinaires et alimentaires, (CNEVA Paris), 43, rue de Dantzig, 75015 Paris, France
\end{abstract}

(Received 17 July 1998; accepted 4 January 1999)

\begin{abstract}
The evaluation of heat damages in commercial milk samples has been studied by an analytical procedure which uses two different and complementary methods. The first is the rapid total sulphydryl (SH) group measurement which evaluates whey protein denaturation. The second involves the measurement of absorbance at $340 \mathrm{~nm}\left(\mathrm{~A}_{340}\right)$ of milks modified with the Clarifying Reagent ${ }^{\circledR}$. At this wavelength some coloured compounds resulting from the non-enzymic browning still absorb. There is a satisfying correlation between $\mathrm{A}_{340}$ and lactulose content $(r=0.98)$ measured in commercial milk samples by using capillary electrophoresis or high performance liquid chromatography (HPLC). Our analytical procedure using SH and $\mathrm{A}_{340}$ measurements has been applied to 130 raw and commercial milk samples. Analysis by Student's $t$-test shows that the values of the two parameters obtained for raw and heat-treated milk samples were significantly different $(P<0.01)$. This study demonstrates that this simple protocol makes possible rapid evaluation of heat damages in commercial milk samples as it could be done with official but more sophisticated methods. (C) Inra/Elsevier, Paris.
\end{abstract}

heat damage / commercial milk / sulphydryl group / absorbance $\mathbf{A}_{\mathbf{3 4 0}}$ / transparent-modified milk / analytical procedure

Résumé - Protocole rapide d'évaluation des traitements thermiques dans les laits de consommation. L'évaluation des dénaturations induites par les traitements thermiques appliqués au lait a été étudiée à l'aide d'un protocole utilisant deux méthodes rapides, différentes mais complémentaires. La première évalue la dénaturation des protéines lactosériques en mesurant les groupements sulfhydryles totaux. La seconde consiste à mesurer l'absorbance à $340 \mathrm{~nm}\left(\mathrm{~A}_{340}\right)$ des laits rendus transparents par l'ajout du réactif de transparisation. $\mathrm{A}_{340}$ est due aux composés issus des réactions de Maillard. Elle est corrélée $(r=0,98)$ avec la teneur en lactulose mesurée par électrophorèse capillaire

* Correspondence and reprints. gerard.humbert@scbiol.u-nancy.fr 
ou HPLC des laits collectés dans les magasins d'alimentation. Ce protocole analytique couplant les mesures des groupements sulfhydryles et de $\mathrm{A}_{340}$ a été appliqué à 130 laits crus ou chauffés. Les valeurs des deux paramètres mesurés sur ces laits sont significativement différentes $(p<0,01)$. Cette étude montre que ce protocole simple permet une évaluation rapide des dénaturations thermiques des laits de consommation comme peuvent le faire les méthodes officielles plus complexes et plus longues. Inra/Elsevier, Paris.

dénaturation thermique / lait de consommation / groupement sulfhydryle / absorbance $\mathbf{A}_{\mathbf{3 4 0}}$ / lait transparisé / méthode d'évaluation

\section{INTRODUCTION}

Heating of milk affects its physicochemical, nutritional and organoleptic properties. Protein denaturation and Maillard reactions are among the most important and undesirable consequences [2]. Pasteurisation and UHT (Ultra High Temperature) treatment produce only minor changes in casein but whey proteins are more denaturated. The in-bottle sterilisation may also cause changes in casein micelle structure.

The principal methods proposed for the evaluation of heat damages in commercial milks can be classified into two types. The first one quantifies directly or indirectly the whey protein denaturation while the second measures the consequences of the Maillard and associated reactions.

The compounds formed in the Maillard and associated reactions are often used as indicators of heat damage, such as hydroxymethylfurfural (HMF), furosine, lactulosyllysine and carboxy-methyllysine [17]. The development of the Maillard reactions in milk can also be monitored by free fluorescent intermediary compounds [13]. A good correlation between HMF and furosine contents has been found in commercial milks $[5,6]$. Furosine and lactulose are good indicators of heat damages in UHT and inbottle sterilised milks and are increasingly used parameters. They are also well correlated with each other $[12,16,18]$.

Cheng et al. [3] reported that some of the coloured compounds resulting from non- enzymatic browning, such as melanoidins and humic acids, have ultraviolet absorption maxima between 265 and $300 \mathrm{~nm}$. They still absorb at $340 \mathrm{~nm}$. Choukri et al. [4] studied the absorbance spectra of transparent-modified raw and heated milks between 320 and $500 \mathrm{~nm}$. The wavelength $340 \mathrm{~nm}$ was chosen because there is no significant interference by milk constituents and the Clarifying Reagent ${ }^{\circledR}$. Choukri et al. [4] reported that absorbance at $340 \mathrm{~nm}\left(\mathrm{~A}_{340}\right)$ of raw and pasteurised samples were only slightly different but there were significant differences between raw and UHT milk samples $[4,14]$. The relative standard deviation (RSD) of $\mathrm{A}_{340}$ for different classes of milk samples was found by Choukri et al. [4] to vary from $2.8 \%$ (mean value 0.221 , $n=31$ ) for in-bottle sterilised milk to $3.1 \%$ (mean value $0.099, n=32$ ) for pasteurised milk. In any case, RSD are smaller than those reported by Morales et al. [14], which were $4.9 \%$ (mean value $0.282, n=9$ ) and $4.8 \%$ (mean value $0.088, n=8$ ), respectively. Moreover, $\mathrm{A}_{340}$ was well correlated with the HMF content of raw and commercial milk samples [4, 14].

At present, there is no single method that allows the complete characterisation of all types of heat-treated milk. The measurement of whey protein denaturation makes it possible to differentiate between raw, pasteurised and UHT milks. Products of heat damage such as lactulose, furosine and HMF seem suitable for characterising UHT and in-bottle sterilised milks, or for estimating the severity of heat treatment of these types 
of milk $[1,7,9]$. The use of both criteria may be useful for a better characterisation of milk samples. However, many of these analyses are time-consuming or require sophisticated equipment.

This study reports on the linear correlation between $\mathrm{A}_{340}$ and lactulose content measured by capillary electrophoresis and high performance liquid chromatography (HPLC). An analytical procedure is finally proposed for studying the severity of heat treatment of commercial milk samples. It uses total sulphydryl ( $\mathrm{SH}$ ) group determination and $\mathrm{A}_{340}$ measurement of transparent-modified milk samples. This procedure was carried out on 130 samples including individual raw milks and commercial-heated milks. A statistical study was used to validate this rapid protocol.

\section{MATERIALS AND METHODS}

\subsection{Milk samples}

Raw milk samples from individual cows were collected on a farm. Commercial pasteurised, UHT and in-bottle sterilised milk samples used for $\mathrm{SH}$ content and $\mathrm{A}_{340}$ measurements were purchased at the local market. Other milk samples were collected from European countries for studying the correlation between lactulose content and $\mathrm{A}_{340}$. The pasteurisation treatment was generally carried out at $72-75^{\circ} \mathrm{C}$ for $20-50 \mathrm{~s}$ on plate heat exchangers. UHT treatment after a heat pretreatment was performed by direct or indirect heating on plate or tubular heat exchangers at $140-145^{\circ} \mathrm{C}$ for $2-6 \mathrm{~s}$. In-bottle sterilisation was carried out at $120^{\circ} \mathrm{C}$ for $15-20 \mathrm{~min}$ after pasteurisation and UHT treatments. The exact heat load was never known for any of these procedures.

\subsection{Measurement of the $A_{340}$ of transparent-modified milk samples}

The protocol was previously described by Choukri et al. [4]. The authors pointed out the slight influence of fat content on $\mathrm{A}_{340}$. According to their results, measurements have to be carried out on samples having known fat content. $\mathrm{A}_{340}$ experimental values should be consequently corrected knowing that $1 \mathrm{~g}$ of milk fat per liter produces an absorbance increase of $1.10^{-3}$ unit at this wavelength. A $2.4 \mathrm{~mL}$ aliquot of Clarifying Reagent ${ }^{\circledR}$ [11] (Prolabo, Fontenay-sous-Bois, France) was added to a $1.5 \mathrm{~mL}$ milk-water mixture $(1: 1, v / v)$. The mixture was shaken vigorously and incubated for $5-8 \mathrm{~min}$ at $37^{\circ} \mathrm{C}$. The absorbance of the transparent mixtures was measured at $340 \mathrm{~nm}$ on a Shimadzu MPS $2000 \mathrm{spec}-$ trophotometer (Roucaire, Courtaboeuf, France) within the next $20 \mathrm{~min}$ against a blank containing $1.5 \mathrm{~mL}$ water and $2.4 \mathrm{~mL}$ Clarifying Reagent ${ }^{\circledR}$.

\subsection{Measurement of lactulose content}

\subsubsection{HPLC method}

The lactulose content was determined by using a standard method [10] on an HPLC equipment (Waters, Milford, MA, USA) consisting of a $600 \mathrm{E}$ multisolvent delivery system, a Wisp 712 automatic sample processor, a 410 differential refractometer, and controlled by Millennium 2010 Chromatography Manager software. Two columns in series were used and the flow rate was $0.6 \mathrm{~mL} \cdot \mathrm{min}^{-1}$.

\subsubsection{Capillary electrophoresis method}

Capillary electrophoresis was carried out on a Quanta 4000 model (Waters, Milford, MA, USA) with a fused silica capillary of $50 \mu \mathrm{m}$ i.d., and an effective length of $930 \mathrm{~mm}$ (Supelco, Bellefonte, PA, USA). Lactulose content was measured with the modified method of Vorndran et al. [19], which is a ultraviolet inverse detection at $254 \mathrm{~nm}$ in the presence of $4 \mathrm{mmol} \cdot \mathrm{L}^{-1}$ sorbate buffer at $\mathrm{pH} 12.04$. The applied voltage was $10 \mathrm{kV}$ and the injection time $18 \mathrm{~s}$. Fructose (115 $\mathrm{mg} \cdot \mathrm{L}^{-1}$ ) was added as an internal standard. Milk samples were diluted with ultrapure water $(1: 25, v / v)$ and loaded by hydrostatic injection on the capillary system without any other treatment. The capillary electrophoresis method is not yet an official method, thus it has been compared to the HPLC method. A preliminary study carried out on 16 UHT and in-bottle sterilised milk samples has shown that there was a high correlation between the results for the two methods of lactulose determination (capillary electrophoresis lactulose content $\mathrm{mg} \cdot \mathrm{L}^{-1}=0.939$ 
[HPLC lactulose content $\mathrm{mg} \cdot \mathrm{L}^{-1}$ ] -41.61 ; $r=0.984)$. Lactulose values obtained by capillary electrophoresis were slightly lower than those measured by HPLC.

\subsection{Determination of total sulphydryl groups}

Sulphydryl groups were determined according to Guingamp et al. [8] using 5,5'-dithio-bis (2-nitrobenzoic acid) (DTNB) from Sigma Chemical Co. (St. Louis, MO, USA). To $0.5 \mathrm{~mL}$ of the milk sample, if necessary diluted $1: 1$ with distilled water was added $I \mathrm{~mL}$ of $8 \mathrm{~mol} \cdot \mathrm{L}^{-1}$ urea buffered solution $\left(0.03 \mathrm{~mol} \cdot \mathrm{L}^{-1}\right.$ borate buffer ajusted to $\mathrm{pH} 8.5$ with boric acid) and $50 \mu \mathrm{L}$ of DTNB solution $\left(4 \mathrm{mg} \cdot \mathrm{mL}^{-1}\right.$ of $0.2 \mathrm{~mol} \cdot \mathrm{L}^{-1}$ EDTA pH 6 solution). The mixture was shaken gently and kept 3 to $5 \mathrm{~min}$ at room temperature. Then $0.5 \mathrm{~mL}$ of $0.2 \mathrm{~mol}, \mathrm{~L}^{-1}$ EDTA solution at $\mathrm{pH} 6$ and $2 \mathrm{~mL}$ of Clarifying Reagent ${ }^{\otimes}$ were added; the solution was shaken vigorously and the tubes placed at $37^{\circ} \mathrm{C}$ for 3 to $5 \mathrm{~min}$. Absorbance $\left(A_{S}\right)$ of the transparent-modified mixture was read at $412 \mathrm{~nm}$ (within $20 \mathrm{~min}$ ) against a blank tube containing all reagents except milk. Another blank sample (BM) that contained all reagents except DTNB was prepared to substract the small absorbance of transparent-modified milk. Its absorbance $\left(A_{B M}\right)$ was read against a solution containing all reagents except milk and DTNB. The final absorbance $\left(A_{F}\right)$ used for the calculations was given by: $A_{F}=A_{S}-A_{B M}$. The $\mathrm{SH}$ amounts of the samples were calculated from cysteine hydrochloride standard curve $\left(0-10^{-7} \mathrm{~mol} \cdot \mathrm{L}^{-1}\right.$ per tube).

\section{RESULTS AND DISCUSSION}

\subsection{Correlation between $\mathbf{A}_{340}$ and lactulose content}

$\mathrm{A}_{340}$ and lactulose contents determined by capillary electrophoresis were measured for 31 samples of raw, commercial UHT and in-bottle sterilised milks. Raw milk samples were analysed to obtain the minimal values for $\mathrm{A}_{340}$ and lactulose contents. These two parameters were highly correlated $\left(\mathrm{A}_{340}=0.19610^{-3}\right.$ [lactulose content $\mathrm{mg} \cdot \mathrm{L}^{-1}$ ] $+0.070 ; r=0.963, n=31$ ) as shown in figure 1. Moreover, these two parameters cor- relate well within UHT ( $r=0.89, n=12$ ) and within in-bottle sterilised $(r=0.93$, $n=16$ ) milk samples. Analysis by Student's $t$-test pointed out that $\mathrm{A}_{340}$ and lactulose contents were significantly different $(P<0.001)$ inside each class of milk samples. Mean values for lactulose content were $426 \mathrm{mg} \cdot \mathrm{L}^{-1}(\mathrm{RSD}=28.7 \%)$ for UHT milk samples and $948.8 \mathrm{mg} \cdot \mathrm{L}^{-1}(\mathrm{RSD}=17.4 \%)$ for in-bottle sterilised milk samples. Mean values for $\mathrm{A}_{340}$ were $0.153(\mathrm{RSD}=16.3 \%)$ for UHT milk samples and 0.257 (RSD $=15.5 \%$ ) for in-bottle sterilised milk samples. The relatively high coefficient of variations was due to the wide ranges of the temperature-time conditions applied to these classes of commercial milks. Morales et al. [14] found the same range of $A_{340}$ values on industrial processed milks and came to similar conclusions. Moreover, in a kinetic study these authors found a temperaturedependence of $\mathrm{A}_{340}$ and a zero order kinetics in milk and in model systems.

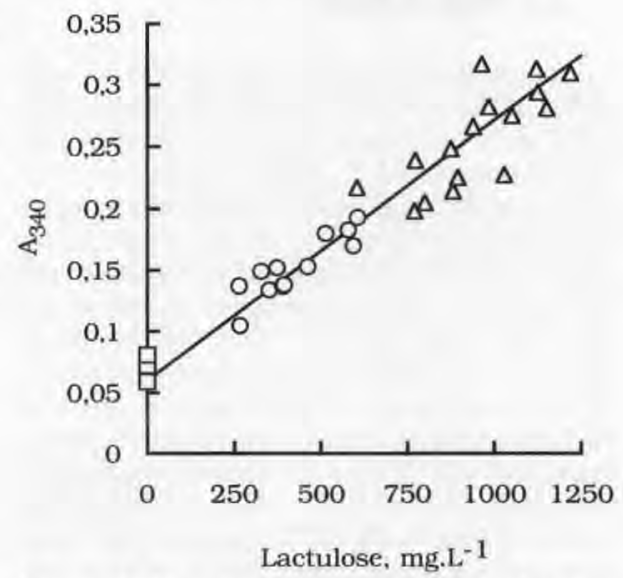

Figure 1. Correlation between $\mathrm{A}_{340}$ and lactulose content measured by capillary electrophoresis of raw $(\square)$, commercial UHT $(O)$ and in-bottle sterilised $(\Delta)$ milk samples. $A_{340}$ $=0.19610^{-3}$ (lactulose content $\left.\mathrm{mg} \cdot \mathrm{L}^{-1}\right)+0.070$; $r=0.963, n=31$.

Figure 1. Corrélation entre $\mathrm{A}_{340}$ et la teneur en lactulose mesurée par electrophorese capillaire de laits crus ( $\square$ ), des laits de consommation UHT (O) et stérilisés en bouteille $(\triangle) \cdot A_{340}=0,196$ $10^{-3}$ (lactulose $\mathrm{mg} \cdot \mathrm{L}^{-1}$ ) $+0,070 ; r=0,963$, $n=31$. 


\subsection{Analytical procedure to evaluate heat treatment of commercial milk samples}

In a previous report [8], it had been observed that total SH decreased when heating was more severe. These measurements had permitted a differentiation of raw, pasteurised and sterilised milk samples. However, it was impossible to distinguish drastic UHT-sterilised and in-bottle sterilised milk samples because their total SH contents are close to zero. In similar experiences, Pagliarini et al. [15] measured the soluble whey proteins instead of total SH and came to the same conclusion.

On the contrary, furosine and more often lactulose are considered as good indicators for intensive heating $[1,2,6]$. Good correlation factors between HMF and furosine, lactulose and furosine, lactulose and HMF were previously reported [9]. At present it is also recognised that furosine is a better indicator for mild treatment and some authors report a non-linear but polynomial correlation between lactulose and furosine levels in UHT or sterilised milks [12]. $\mathrm{A}_{340}$ has been demonstrated to be well correlated with HMF [4, 14]. Recently, Morales et al. [14] reported also a good correlation between $\mathrm{A}_{340}$ and different parameters such as the loss of available lysine, or free fluorescent intermediary compounds formed in the Maillard reactions.

In addition, the present work points out the correlation between $\mathrm{A}_{340}$ and lactulose content. All these results validate $\mathrm{A}_{340}$ measurements for a good evaluation of severe and variable heat treatments.

In principle, the use of two complementary parameters allows a more precise evaluation of heat severity in milk $[15,17]$. In our study the first parameter (i.e. SH content) measures the extent of soluble protein denaturation, essential for low-heated milks, and the second one (i.e. $\mathrm{A}_{340}$ ) measures the extent of the Maillard or associated reactions characterising the more drastic heat treatments.

The values for $\mathrm{SH}$ content and $\mathrm{A}_{340}$ for 130 milk samples are reported in table I.

Table I. Sulphydryl content and $\mathrm{A}_{340}$ for raw and commercial partly skimmed milk samples.

Tableau I. Teneurs en groupements sulfhydryles et $\mathrm{A}_{340}$ de laits crus et des laits de consommation demi-écrémés.

\begin{tabular}{|c|c|c|c|c|}
\hline & \multicolumn{4}{|c|}{ Type of milk } \\
\hline & Raw & Pasteurised & UHT & $\begin{array}{l}\text { In-bottle } \\
\text { sterilised }\end{array}$ \\
\hline Number of samples & 29 & 34 & 35 & 32 \\
\hline $\begin{array}{l}\text { Sulphydryl content } \\
\text { ( } \mu \text { mol.g } \mathrm{g}^{-1} \text { non-fat dry solids) } \\
\text { Mean } \\
\text { Range } \\
\text { RSD }(\%)\end{array}$ & $\begin{array}{c}1.46 \\
0.72-2.21 \\
26.0\end{array}$ & $\begin{array}{c}0.98 \\
0.69-1.41 \\
16.3\end{array}$ & $\begin{array}{c}0.44 \\
0.10-0.73 \\
36.4\end{array}$ & $\begin{array}{c}0.15 \\
0.0-0.39 \\
73.3\end{array}$ \\
\hline $\begin{array}{l}\mathrm{A}_{340} \\
\quad \text { Mean } \\
\text { Range } \\
\text { RSD }(\%)\end{array}$ & $\begin{array}{c}0.081 \\
0.061-0.098 \\
13.5\end{array}$ & $\begin{array}{c}0.095 \\
0.083-0.108 \\
7.4\end{array}$ & $\begin{array}{c}0.124 \\
0.093-0.165 \\
13.7\end{array}$ & $\begin{array}{c}0.222 \\
0.158-0.287 \\
14.9\end{array}$ \\
\hline
\end{tabular}

RSD: relative standard deviation.

UHT : Ultra High Temperature. 
Analysis by Student's $t$-test showed that the values of the two parameters obtained for raw and heat-treated milk samples were significantly different $(P<0.01)$. These findings are of interest because the heat treatment history of the commercial milk samples is never exactly known. These two measurements permit a characterisation of heat load of unknown samples when compared to mean values obtained for each class of milk samples (table I).

In figure 2 the area drawn for each class of samples is defined by the confidence intervals at $95 \%$ for mean values for $\mathrm{SH}$ content and $\mathrm{A}_{340}$. All the heat-treated milks were well differentiated, excepted raw and pasteurised samples which had a partial common area. This could be partly explained because raw milk samples were individual milk samples collected over 1 year. A previous study [8] showed that SH content depends on the season. Moreover, there was only one sample of raw milk in the common area between raw and pasteurised milk samples. Variations in SH content were minimised in commercial milk

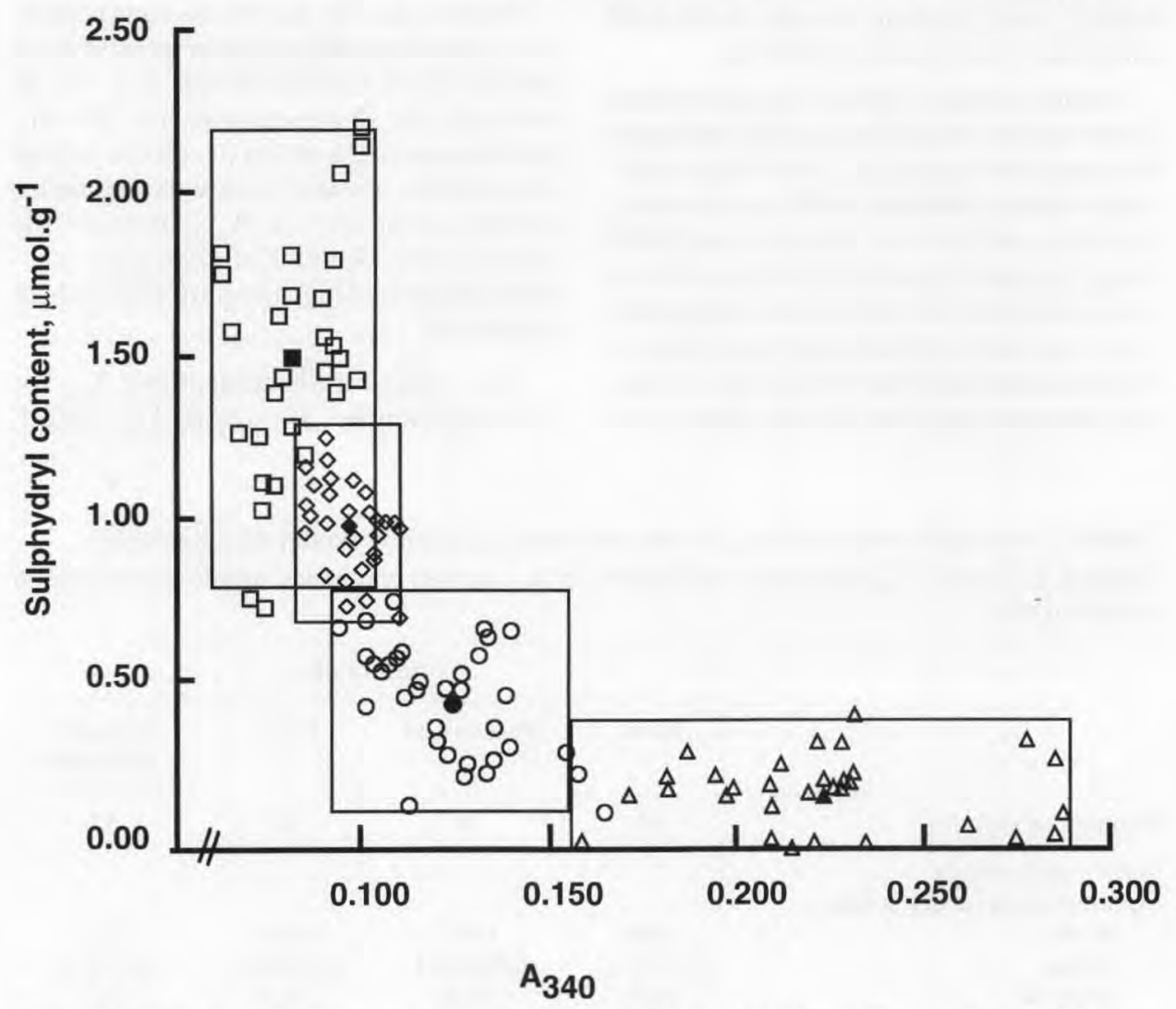

Figure 2. Sulphydryl group content ( $\mu \mathrm{mol} \mathrm{SH} \cdot \mathrm{g}^{-1}$ non-fat dry solids) of raw $(\square)$, pasteurised $(\diamond)$, commercial UHT $(O)$ and in-bottle sterilised $(\triangle)$ milk samples plotted versus $A_{340}$ of the transparent-modified milk samples. Mean values are indicated with filled black symbols. The four boxed areas are defined with a $95 \%$ confidence interval.

Figure 2. Teneurs en groupements sulfhydyles ( $\mu \mathrm{mol} \cdot \mathrm{SH} \cdot \mathrm{g}^{-1}$ extrait sec dégraissé) et $\mathrm{A}_{340}$ de laits crus $(\square)$, pasteurisés $(\diamond)$, UHT $(\bigcirc)$ et stérilisés en bouteille $(\triangle)$. Les valeurs moyennes sont indiquées en symboles pleins. Les quatre aires ont été tracées avec un intervalle de confiance de $95 \%$. 
samples because they were treated in bulk. Pasteurised and UHT milk samples also had a small common area. It could be due to a too severe pasteurisation treatment, which may produce nearly the same heat damage as those observed in mild UHT treatment.

\section{CONCLUSION}

This analytical procedure makes use of two complementary measurements, $\mathrm{A}_{340}$ and $\mathrm{SH}$ content. It follows the present analytical tendency taking into account that a single parameter is insufficient to characterise a heat treatment. The main advantage of the proposed procedure, in comparison with the standard methods using HPLC or other sophisticated laboratory technologies, is its simplicity. It could therefore be very helpful in a screening in-house control.

\section{REFERENCES}

[1] Andrews G., Lactulose in heated milk, Int. Dairy Fed. Bull. 238 (1989) 45-66.

[2] Burton H., Reviews of the progress of dairy science: the bacteriological, chemical, biochemical and physical changes that occur in milk at temperatures of $100-150{ }^{\circ} \mathrm{C}, \mathrm{J}$. Dairy Res. 51 (1984) 341-363.

[3] Cheng H.T., Lin W.F., Wang C.R., Studies on the color development in stored plantation white sugars, in: Proceedings of the 183th Meeting of the American Chemical Society, Las Vegas, CA, Symposium series, 1983, pp. 90-101.

[4] Choukri A., Guingamp M.F., Humbert G., Linden $\mathrm{G}$., A new analytical procedure to differentiate heated commercial milks, in: Proceedings Strategies for Food Quality Control and Analytical Methods in Europe, Eur. Food Chem. VI, Hamburg, vol. II, 1991, pp. 563-568.

[5] Dehn-Müller B., Müller B., Erbersdobler H.F., Untersuchungen zur Proteinschädigung in UHTMilch, Milchwissenschaft 46 (1991) 431-434.

[6] Erbersdobler H.F., Dehn-Müller B., Formation of early Maillard products during UHT treatment of milk, Int. Dairy Fed. Bull. 238 (1989) 62-68.
[7] Fink R., Kessler H.G., Comparison of methods for distinguishing UHT treatment and sterilization of milk, Milchwissenschaft 43 (1988) 275-279.

[8] Guingamp M.F., Humbert G., Linden G., Determination of sulphydryl groups in milk using Ellman's procedure and Clarifying Reagent ${ }^{\circledast}$. J. Dairy Sci. 76 (1993) 2152-2155.

[9] Hewedy M.M., Kiesner C., Meissner K., Hartkopf J., Erbersdobler, H.F., Effects of UHT heating of milk in an experimental plant on several indicators of heat treatment, J. Dairy Res. 61 (1994) 305-309.

[10] International Dairy Federation (IDF), Heat treated milk. Determination of lactulose content - high performance liquid chromatography method, Standard 147A, 1994.

[11] Linden G., Humbert G., Guingamp M.F. (inventors), Reagent for rendering biological fluids transparent and its analytical applications, University Nancy 1, assignee European Patent Application EP 0246978B1, 1987.

[12] Montilla A., Calvo M.C., Santa-Maria G., Corzo N., Olano A., Correlation between lactulose and furosine in UHT-heated milk, J. Food Protect. 59 (1996) 1061-1064.

[13] Morales F.J., Romero C., Jimenez-Perez S., Fluorescence associated with Maillard reaction in milk and milk resembling systems, Food Chem. 57 (1996) 423-428.

[14] Morales F.J., Romero C., Jimenez-Perez S., Application of the Clarifying Reagent Index as a heat-induced parameter in commercial milk, J. Food Protect. 59 (1997) 124I-1246.

[15] Pagliarini E., Iametti S., Peri C., Bonomi F, An analytical approach to the evaluation of heat damage in commercial milks, J. Dairy Sci. 73 (1990) 41-44.

[16] Pellegrino L., Denoni I., Resmini P., Coupling of lactulose and furosine indices for quality evaluation of sterilized milk, Int. Dairy J. 5 (1995) 647-659.

[17] Pellegrino L., Resmini P., Luf W., Assessment (indices) of heat treatment of milk, in: Heat Induced Changes in Milk, Int. Dairy Fed. special issue 9501 (1995) 409-455.

[18] Van Renterghem R., De Block J., Furosine in consumption milk and milk powders, Int. Dairy J. 6 (1996) 371-382.

[19] Vorndran A.E., Oefner P.J., Scherz H., Bonn G.K., Indirect UV detection of carbohydrates in capillary zone electrophoresis, Chromatographia 33 (1992) 163-167. 